higher animals. M. H. Goll of Lausanne, presented a contribution to the natural history of the sedentary and migratory coregones of Lake Neuchâtel. Memoirs were received on the Arachnidxe of Switzerland by Prof. Pavesi of Pavia; on the fauna of Guatemala, by Dr. Otto Stoll of Zurich; on some new species of Medusæ from. the Red Sea, by Dr. Keller of Zurich ; on the Pelasgic fauna of the Swiss lakes, by Dr. OthmarEmile Imhof of Zurich; and on the influence of the physicochemical environments on the deveinpment of the tadpole of the edible frog, by M. E. Yung of Geneva. From experiments made by mixing marine salt in various proportions with the natural freshwater element, M. Yung arrived at the conclusion that, the more saline the water, the slower is the development of the tadpole, all transformations ceasing in solutions of $9 / 1000$, and death foll wing in a few hours in solutions of $10 / 1000$.

In the Botanical Section, Prof. Cremer, president, valuable memoirs were received from Prof. O. Heer of Zurich, on the Glacial flora of Switzerland, and on the fossil flora of Greenland. These were the last pages contributed to science by the distinguished savant, who had scarcely finished the revisal of the proofs when he died suddenly at Lausanne, on September 27. A series of hybrids between the Primula auricula and Primula viscosa, showing an uninterrupted series of forms intermediate between these two species, was exhibited by Prof. Favart of Lausanne. He also showed that the Cardamine fossicola, Godet, hitherto classed with the $C$. pratensis, Lin., should be grouped with the $C$. matthioli, Moretti. Some remarks were made by Prof. Schnetzler of Lausanne on a monstrosity of the Chinese primrose, and on the relation between an aërial alga (Chroolepus umbrinus) and a lichen (Pyremulasp.) M. C. de Candolle described the results of his attempts to determine how far any light may be thrown on the disputed origin of the Cytisus adami by the anatomical structure of its leaves. This plant, which suddenly made its appearance in the nursery of Adam at Vitry, near Paris, early in the pre-ent century, and which is remarkable for producing red and yellow blossoms mostly on separate branches, is usually regarded as a cross obtained by grafting the Cytisus purpureus on the C. laburnum. But $\mathrm{M}$. de Candolle concludes that it is not a hybrid, but simply a degenerate variety of the $C$. laburnum.

In the Medical Section, Prof, von Kölliker, president, Prof. Klebs of Zurich read a remarkable paper on the transformations of the human species, which he regards as mainly the result of pathological influences.

Valuable communications were also made on the centres of origin of the optic nerves and on their relation to the cerebral cortex, by Dr. C. von Monakow of St. Petersburg ; on the relations existing between the excitability and vulnerability of certain muscular groups, by Prof. Luchsinger of Berne ; and on the mechanism of the ruminating proce is, by the same author.

The report on the Geological Section was unavoidably postponed to the November issue of the Archiv.s.

\section{NOTES FROM THE OTAGO UNIVERSITY MUSEUM}

IV.-On the Structure of the Head in "Palinurus," with special reference to the Classification of the Genus 1

THE genus Palinurus was divided bv Milne-Edwards into two groups or sub-genera-one, the "Langoustes ordinaires," containing species in which the antennulary flagella are short, the bases of the antennæe approximated, and the rostrum present ; while the other, or "Langoustes longicornes" (Panulirus, Gray; Senex, Pfeiffer), contains species in which the antennulary flagella are short, the antennæ widely separated at their proximal ends, and the rostrum absent.

In this classification, which is still in the main adopted by systematists, no notice is taken of the stridulating organ, first mentioned, I believe, by Leach, in P. vulgaris, and described at length by Möbius, and later by myself, in the same species. ${ }^{2}$ This unique sound-producing apparatus is present in all the "Langoustes longicornes" which I have yet examined, as well as in P. vulgaris and P. trigonus among the "Langoustes ordinaires"; while in all the remaining members of the latter group

${ }^{x}$ Abstract of a paper taken as read at a meeting of the Otago Institute, September 12, 1883 , and to be published in the next (16th) volume of the Transactions of the New Zealand Institute.

"Leach, "Malacostraca podophthalmata Britannize": Möbius, Archiv fur Naturgeschichte, r867; T. J. Parker, Proc. Zool. Soc., x878, p. $44^{2}$. which have come under my notice (e.g. the common New Zealond species, $P$. lalandii and $P$. edwardsii $)$ there is no trace of it.

There is also great diversity among the "Langoustes ordinaires" in the development of the rostrum, the true size of which can only be seen in a longitudinal vertical section of the head (see Fig. I). In P. lalandii and other non-stridulating species, the rostrum $(\mathrm{A}, \tau)$ is well developed, and bears comparison with that of Homarus, while in $P$. vulgaris $(\mathrm{B}, r)$ it is a mere spiniform tubercle meriting special description only from its position. $P$. vulgaris, moreover, has no trace of procephalic processes, which are present, though small, in $P$. lalandii (A, pc. $p$ ).
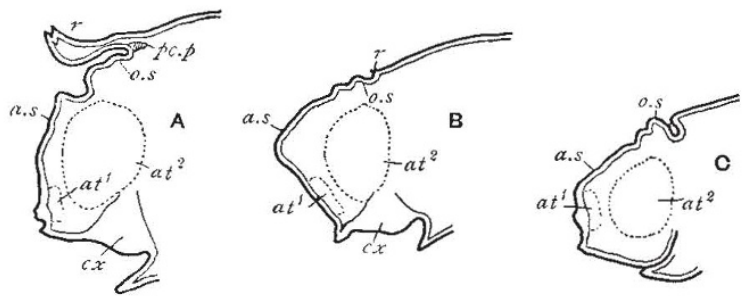

FIG, I-A, Longitudinal vertical section of the head of Palinurus edzuardsii: $\mathrm{B}$, of $P$. vulgaris : $\mathrm{C}$, of $P$. interruptus. as, antennulary sternum; at ${ }^{\mathrm{L}}$, articular cavity for antennule; $a t^{2}$, for antenna; $c x$, unanchylosed part of inner wall of coxocerite; $0 . s$, ophthalmic sternum; $r$, rostrum; $p c . p$, procephalic process.

The woodcut shows that as regards both the rostrum and the antennulary sternum (the fixed part of the stridulating organ), $P$. vulgaris (B) approaches far more nearly to the "Langoustes longicornes," as represented by $P$. interruptus (C), than to the non-stridulating "Langoustes ordinaires," as represented by $P$. edruardsii (A).

On the other hand, all the brevicorn species examined agree in the imperfect fusion of the coxocerites or proximal segments of the antennæ. A transverse section taken immediately in front of the renal apertures shows that a small portion of the adjacent or inner walls of the coxocerites in P. lalandii, P. vulgaris, \&c., are merely in apposition, whereas in the longicorn species concrescence is complete.

Assuming that the Palinurida are derived from an Astacoid or Homaroid ancestor through some such intermediate form as Palinurellus, one cannot but conclude that the species which have no stridulating organ, a well-develofed rostrum, procephalic processes, and imperfectly fused coxocerites, come nearest to the parent stock, and that those in which the stridulating organ is developed, the rostrum and procephalic processes absent, and the coxocerites completely united with one another, have diverged most from that stock, and present us with the extreme of modis fication of the Palinuroid type.

This view is expressed in the following phylogenetic table :-

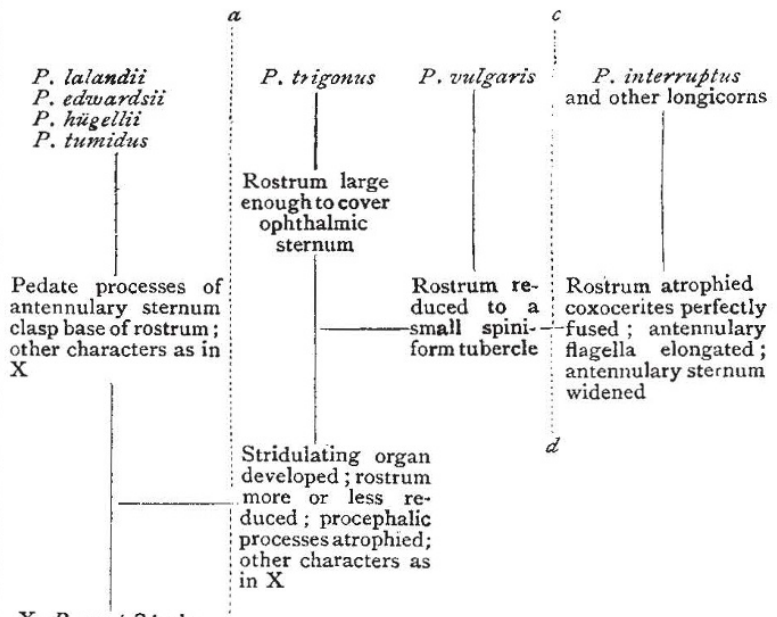

X. Parent Species. No stridulating organ ; rostrum well developed; procephalic processes present; coxocerites impernulary flagella short 
In a natural classification of the genus the most fundamental separation appears to me that along the dotted line $a b$ dividing the non-stridulating from the stridulating species. This division once made, the stridulating species fall into two natural subdivisions, expressed in the table by the line $c d$, which divides the brevicorn from the longicorn forms.

I think the most convenient classification is obtained by dividing the species along the two lines $a b, c d$ into three subgenera, one identical with the "Langoustes longicornes" of Milne-Edwards, the others formed by splitting up the "Langoustes ordinaires" into species with and species without a stridulating organ.

The following table embodies the proposed arrangement :-

Genus Palinurus, Fabr.

A. Stridulating organ absent; rostrum well developed, clasped by paired pedate processes of the antennulary sternum ; procephalic processes present; coxocerites imperfectly fused; antennulary flagella short (sub-genus Fasus, T. J.P.) $P$. lalandii, $P$. edrvardsii, $P$. hügellii, $P$. tumidus.

B. Stridulating organ present ; rostrum variable, but rarely (? never) as well developed as in (A); pedate clasping processes absent ; procephalic proces:es absent.

a. Antennulary sternum narrow below, bases of antennules being hidden, in a view from above, by bases of antennæ; coxocerites imperfectly fused; antennulary flagella short (sub-genus Palinurus).

a. Rostrum well developed, covering ophthalmic sternum. P. trigonus.

B. Rostrum reduced to a small spiniform tubercle; ophthalmic sternum uncovered.

P. vulgaris.

b. Antennulary sternum broad below, bases of antennules being visible from the dorsal a pect; coxocerites perfectly fused; antennulary flagella long (sub-genus Panulirus, Gray; Senex, Pfeiffer).

P. interruptus, $P$. fasciatus, \&c., \&c.

Dunedin, N.Z., October 2

T. JEFFERY PARKER

\section{SCIENTIFIC SERIALS}

Bulletin of the Belgian Royal Acadsmy of Sciences and Belles Lettres, October 4.- Obiturary notices of the late M. Joseph Plateau, by MM. Duprez, Valerius, and Liagre.-Second communication on the discovery of the fossil iguanodon at Bernis. sart, by P. J. Van Beneden,-Researches on the absolute force of the muscles of the Invertebrates; Part I. Absolute force of the adductor muscles in the lamellibranch mollnscs (four illustrations), by M. Félix Plateau. - Note on a new optical illusion, by H. Valerius.-Remarks on the action of lightning conductors constructed on the Melsens system, by $\mathrm{H}$. Valerius. - Arithmetical and algebraic theorems, by E. Catalan. - Note on the pelvisternum in the Edentates (ten illustrations), by Prof. Paul Albrecht.-Funeral oration of M. Henri Conscience in Flemish and French, by M. Pierre Willems.-Memoir on the bibliography of international law before the publication of Grotius's "Jus belli et pacis" (1625), by Alphonse Rivier.--Confession de Poète, a poem, by Charles Potvin.--Some traits of the social life of the Celestial Empire. How history is mannfactured in China; civil and military decrees, by $\mathrm{Ch}$. de Harlez. - Reports on the competitive papers sent in on the subject of Grétry, a critical study of his life and works. The prize, a gold medal of the intrinsic value of $32 l$., was awarded to M. Michel Breuet of Paris.-Reports on the competitive papers received on the subject of realism, its definition and influence on contemporary painting. The essay by M. Henry Hymans, a member of the Academy, was pronounced the best. But the prize, also a gold medal worth $32 l$., was not awarded to him, owing to his failure to comply with the conditions of the competition. - Discourse on the annual exhibition of paintings, by M. Fetis. The prize of a thousand francs for the best cartoon on the subject of help for the wounded on the battle-field, as a decorative piece for a military hospital, was awarded to M. Henri Evrard, of Saint Gilles-lez-Braxelles.

\section{SOCIETIES AND ACADEMIES LONDON}

Royal Society, December 6.- "The Wave-lengths of A, a, and of some Prominent Lines in the Infra-Red of the Visible Spectrum." By Capt. Abney, R.E., F.R.S.
M. Fievez has recently sent the author a map of the solar spectrum from C to A ("Annales de l'Observatoire Royal de Bruxelles," nouvelle série, tome v.) inclusive, and as part of this region is one which he is measuring, he examined the new publication with great interest. Photography and eye measurements do not coincide in the detail of the grouping of the little $a$ group, or from there as far as A, and A itself is shown by M. Fievez's map as wanting in some details which appear in the photographs. The waverlengths of the different lines from above " $a$ " to A are not tho e given by Fievez, when comparison photographs o the Ist order of the red with the 2nd of the ultra-violet weref taken on the same photographic plate, or when the 2 nd order of the red is compared with the 3 rd order of the green taken in a similar manner. Prof. Rowland's concave gratings were em. ployed for this comparicon. Cornu's map was used as a reference for the ultra-violet wave-lengths, and Ångström's map for those in the blue and green.

\begin{tabular}{|c|c|c|c|c|}
\hline $\begin{array}{l}\text { Description of } \\
\text { line }\end{array}$ & $\begin{array}{c}\lambda \text { from } \\
\text { coimparison } \\
\text { of Ist and } \\
\text { 2nd orders }\end{array}$ & $\begin{array}{c}\lambda \text { from } \\
\text { comparison } \\
\text { of } 2 \text { nd and } \\
3 \text { rd orders }\end{array}$ & $\begin{array}{c}\lambda \text { acconding } \\
\text { to } \mathrm{Fievez}\end{array}$ & Remarks \\
\hline “a" & $\left\{\begin{array}{l}7184^{\circ} 4 \\
7185^{\circ} 4\end{array}\right.$ & $\begin{array}{l}7184^{\circ} 5 \\
7185^{\circ} 4\end{array}$ & $\left.\begin{array}{l}7197 \cdot 7 \\
7198 \cdot 7\end{array}\right\}$ & $\left\{\begin{array}{l}\text { This is shown in } \\
\text { Angström's map } \\
\text { as a single line } \\
\lambda 7184^{\circ} 9 .\end{array}\right.$ \\
\hline $\begin{array}{l}\text { Most refran- } \\
\text { gible edge } \\
\text { of A. }\end{array}$ & $7593^{\circ} 6$ & 759377 & $7600 \cdot 0$ & $\begin{array}{l}\text { Angström gives } \\
7604 \text { for the cen- } \\
\text { tre of this line; } \\
\text { which of the } \\
\text { band se took as } \\
\text { A is not clear. } \\
\text { Langley gave } \\
7600.9 \text { for this } \\
\text { edge. }\end{array}$ \\
\hline $\begin{array}{l}\text { Centre of 6th } \\
\text { pair of lines } \\
\text { in the flut- } \\
\text { ings follow- } \\
\text { ing A. }\end{array}$ & $7644^{\circ} 2$ & $7644^{\circ} 33$ & $7652 \cdot 2$ & \\
\hline
\end{tabular}

The determination of A has been made by Mascart, Smythe, and others, besides Ångström and Langley, with discordant results. The above may be taken as accurate, as are Cornu's and Ångström's maps.

The following are wave-lengths of some of the principal lines in the infra-red. The scale numbers refer to the author's map of the infra-red, which is published in the Phil. Trans., Part II., I880:-

\begin{tabular}{|c|c|c|}
\hline Scale number & Description & Wave-lengths \\
\hline 1046 & $\left.\begin{array}{c}\text { This line is a double, of which } \\
\text { the components have the ac- } \\
\text { companying wave-lengths...... }\end{array}\right\}$ & $\left.\begin{array}{l}8226^{\circ} 4 \\
8229^{\circ} 9\end{array}\right\}$ \\
\hline $\begin{array}{l}\mathbf{1} 44 \mathrm{I} \\
1509 \\
1685\end{array}$ & 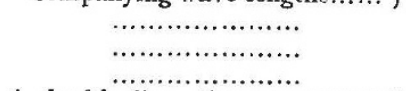 & $\begin{array}{l}8496 \cdot 8 \\
8540^{\circ} 6 \\
8661^{\circ} 0\end{array}$ \\
\hline 2175 & $\left.\begin{array}{c}\text { A double line, the components } \\
\text { of which have the accompany- } \\
\text { ing wave-lengths }\end{array}\right\}$ & $\left.\begin{array}{l}8986 \cdot 2 \\
8989 \cdot 5\end{array}\right\}$ \\
\hline $\begin{array}{l}2638 \\
316 r\end{array}$ & 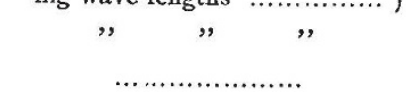 & $\left.\begin{array}{l}9494 \cdot 5 \\
9500 \cdot 1 \\
9633 \cdot 8\end{array}\right\}$ \\
\hline
\end{tabular}

Mathematical Society, December 13.-S: Roberts, F.R.S. vice-president, in the chair. - The following were elected members :-Messrs, A. B. Basset, H. Fortey, R. T. Glazebrook, F.R.S., G. Heppel, J. J. Thomson, H. H. Turner, and Prof W. Thomson, Cape Colony.-The following papers were communicated:-The form of standing waves on the surface of running water, by Lord Rayleigh, F.R.S. - A method of finding the plane sections of a surface and some considerations as to its extension to space of more than three dimensions, by Mr. W. J. 